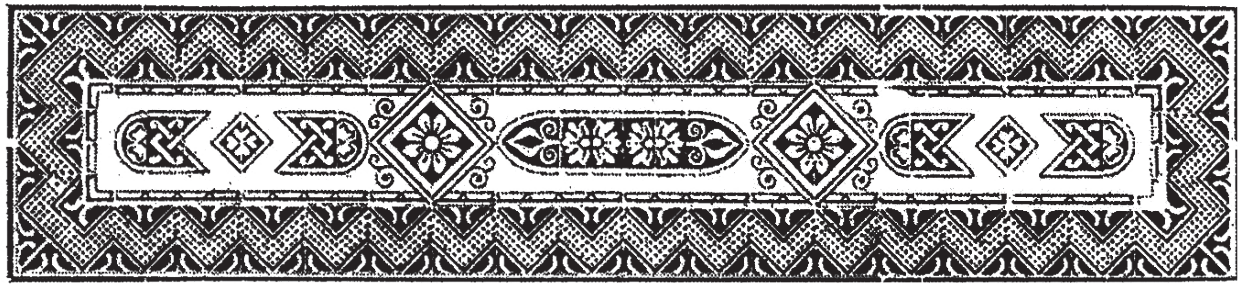

doi https://doi.org/10.18485/bratstvo.2021.25.9 УДК 821.163.41-992.09 Димитријевић J.

Рад примљен: 10. 8. 2021.

Рад прихваћен: 9. 9. 2021.

Оригиналан научни рад

\title{
КОТОРСКИ СУСРЕТИ
}

Кратка путописна проза Утисии с Пута по Нашој Земљи Јелене Димитријевић представља обележја юеног књижевног виђења људи и градова у Краљевини Југославији (1931) током мисије испред Кола српских сестара - Београд. Ређајући градове у Далмащији: Сплит, Дубровник, Котор и друге које је посетила, истицала је сусрете са људима као заједништво које исти говор спаја. А потом, индивидуално сликовито је представила хуманитарни рад тамошьих чланица. Посебан осврт је начинила на чланице Одбора КСС из Котора.

Јелена Димитријевић (1862-1945), песник, приповедач, романсијер, путописац и у мањој мери преводилац, била је позната и као друштвени и национални радник. Већ од 1881, тачније, од доласка у Ниш, удајом, изузетно је ангажована у новоформираном Друштву жена Ниша. Са преласком у Београд (1898), Јелена Димитријевић, поред литерарног стваралаштва, још шире наставља са друштвеним и националним ангажовањем (према потреби тога времена у Србији). Као чланица Београдског женског друштва, које 1911. године прераста у Народни Женски Савез, одговорно ради у његовом литерарном одбору за лист „Домаћица“. Потом, са формирањем друштва Коло Српских сестара, коме се брзо придружује, и као чланица у управи, она једно време обавља, заједно са Бором Станковићем, благајничке послове Кола. Покретањем часописа „Вардар““1, гласила КСС,

\footnotetext{
1 Током његовог постојања (до 1941. године) са краћим прекидима за време Првог светског рата, ту су сарађивали бројни књижевници, историчари, публицисти. Између осталих, Д. Милосављевић наводи следеће: „Петар Кочић, Бранислав Нушић, Војислав Илић, Јован Дучић, Иво Ћипико, Јеремија Живановић, Јелена Димитријевић, Милица
} 
Јелена Димитријевић постаје стални сарадник од 1906. до 1939. године, са својим литерарним радовима.

Од свих жанрова, путописни опус Јелене Димитријевић заузима значајно место, ако не и најзначајније, и то не само по обиму, како је познато, већ и по другим битним карактеристикама које се везују за оваква литерарна остварења. Та њена епистоларна форма, нарочито кроз пријемчиву наративну сликовитост уопште 2 , затим, кроз психолошки осврт у обликовању ликова и кроз дијалошку конверзацију, пружа изузетну документарност људи и крајева из времена њених путешествија, а у свему томе је присутно њено наднационално осећање.

О њеном космополитском размишљању у понашању различитих популација пише (између других) и Владимир Ђурић: Франиуска култура Јелене Димитријевић „Српска душа“ између Истока и Западаз. Сводећи утиске са путовања по Краљевини Југославији у репортажи Утисии с Пута по Намој Земљи, књижевница потенцира и своје национално-родољубиво осећање: „Што се тиче мене не кајем се што сам уместо по Француској путовала по Југославији. На против, радујем се, јер видим да се од свог рода нисам одродила.“4

Са великим светским искуством о положају и правима жена, стеченим током путовања, Јелена Димитријевић, као хроничар свога времена, у делу Са Конгреса износи околности у којима делају светске представнице жена овде присутне - из ближих и далеких земаља. А затим, стављајући акценат на рад Савеза жена у (тадашњој) Југославији, она, тада као присутни посматрач ${ }^{5}$, непристрасно и трезвено коментарише квалитетан рад и успехе овог Савеза. Концепцију о друштвено ангажованим женама на племенитом раду - у Одборима овог Друштва широм Југославије, сада књижевница презентира у путопису Утисци с Пута по Намој Земљи, са посебним освртом на Которски одбор Кола српских сестара. Своје „утиске“ са путовања по градовима Југославије књижевница овде почиње доласком из Словеније на Далматинско приморје.

Са блиц погледом на „Приморје са Сушаком“, смером Далмације ауторка долази до „Сплита са Марјаном“, где са кратком констатацијом износи своје расположење: „Да ли ме више одушевљавао град или море или говор? Заиста, не знам да одговорим. “6 Иза Сплита је посета Солину, а потом одлазак на Плитвице. Иза еуфоричног доживљаја Плитвичких језера

Јанковић, Нико Бартуловић, Алекса Шантић, Десанка Максимовић и многи други...“ Д. Милосављевић, Монографија КСС, Ниш, 2005, 36.

2 И. Секулић, Кюижевни преглед, СКГ, 1934, 604.

Зборник Читате ли Јелену Димитријевић, Београд, 2018, 79-93.

Утисии с Пута по Нашој Земљи, Вардар, 1932, 58.

Мисао, јул-август, 1930, 252-256, 349.

Утисии с Пута по Нашој Земљи, Вардар, 1932, 52. 
стоји опис Сарајева, некад - са почетка XX века (под Аустроугарском) - и сад, скоро три деценије касније (у Краљевини Југославији): „Из Сарајева: винух се према Дубровнику. Кажем, 'винух се', мада не путовах аеропланом, него возом, једним возом који бих хиљаду пута проклела кад он не би пролазио кроз две драге наше земље ... и кад не би ишао у драги наш Дубровник..."7 Са много љубави, а са мало метафоричних реченица, ауторка само освртом пружа слику једног дела дубровачке популације. Иако овде није постојао Одбор КСС, она ту борави два пута, без јасне концепције улоге испред Друштва КСС. Међутим, кад се нађе на следећој дестинацији - у граду Котору, она, поред других обележја тог боравка, поименице наводи которске госпође у Одбору Кола и њихову широку друштвену улогу.

Путописни сегмент о Котору и Боки Которској Јелена Димитријевић започиње једним компаративним доживљајем лепоте овог Залива: „У Котору ... сравњивала сам Которски Залив са Босфором. Па ипак, Которски Залив је лепши. Он је уоквирен брдима као уметничка слика најфантастичнијим оквиром. Јер на овим брдима мењају се боје непрестано. И какви контрасти боја! Из ружичасте за час пређе у плаву или љубичасту. Овакве боје по брдима и овако често, непрестано мењање боја запазила сам још само у Грчкој, и нигде више. Чак ни на Бенгалском Заливу и око залива, где се јутром и вечером, нарочито у сунчев залазак појављују бенгалске ватре.“8 У овом репортерском путописном казивању нема много дескрипције, али је овај бококоторски светлосни феномен нашао своје место у Утисиима наратора. Природни феномени Бококоторског залива су инспиративно деловали и на друге уметнике речи. Један од бројних је и Алекса Шантић (1868-1924), савременик ове књижевнице, који природну лепоту овог предела доживљава и у другим сатима, можда, јутарњим: „покривена небом ко од плаве свиле“, каже поета (Бока, 1906). Апострофни хвалоспев Боки Которској поета је започео метафоричним бајковитим стиховима:

„Наша мила Боко, невјесто Јадрана, покривена небом ко од плаве свиле, љепша си од твоје Приморкиње виле и свјетлија од њеног ђердана““

Међутим, овај Шантићев доживљај лепота Бококоторског залива добија у наставку стиховања другачију конотацију: песникова жеља је да сачува и одбрани ту јединствену природу. Овакав родољубиви поетски осећај је условљен временско-историјским приликама Боке са почетка XX

Исто, 54.

8 Исто. 
века у односу на слободну Боку, 25 година касније, и Јеленину усхићеност тада.

Лепота которског окружења као и сам град Котор, али много више сусрети и дружење са чланицама Кола овог града, уз сећање или подсећање на нека ранија познанства, и, ,jа остах читаву недељу дана“ - износи књижевница Димитријевић, као оправдање за планирани „само један дан“. Ауторка поименице ређа Сестре-Которке које су јој остале у „духовним очима“ - док пише Утиске. Биле су то госпође: „Ема Стефановић, рођена Липовац, председница Кола Српских Сестара, Драга Крамер, рођена Жуткић, потпредседница, Антица Дабиновић, тајник, Јосипа Галвани, Софија Гозденовић са својом ћерком госпођицом Илинком, и - Аида Толентино, лепа Аида Толентино... О госпођи Олимпији Вукотић, рођеној Руцовић, удови Ђура Вукотића, општинског начелника и народног заступника, а сестри неумрлог Руцовића, првака наше драме - да не говорим. Она ми је одавнашња познаница, из Рима. У Котор дођох због ње, мада се у Котору задржах због свих сестара..."9 Од ових чланица Кола нараторка приближава минијатурни али духовно јак портрет „тајнице“ овог Одбора, Антице Дабиновић. Са њом се већ једном срела: „на последњој скупштини“ у Београду, са које је књижевница Димитријевић, из званичног и песнички обликованог реферата понела утисак о високо интелектуалној личности. Још једна особа из Одбора блиска књижевници Јелени јесте „одавнашња познаница из Рима““, госпођа Олимпија Вукотић. О њој је наратолошко обавештење из другог угла: са породичним и помало генеалошким везама, осветљена је (репортерски) блиска пријатељица - госпођа Вукотић. Которски сусрети носе и шире сазнање како о мештанкама тако и о ширини пријатељица и пријатељстава књижевнице Димитријевић.

Наратолошки поступак у целом путописном тексту начињен је тематски од доживљаја и утисака, нарочито у Котору. У идејном погледу, кроз контекстуалност овог сегмента, даје се примат духовној страни заједништва - са основицом говора. Потенцирањем заједништва у читавој (тадашњој) Југославији са истим или сличним конверзационим карактеристикама, књижевница Јелена Димитријевић у тексту закључује: „Једнокрвну

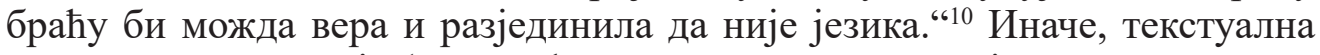
стилска организација (по утврђеним методама и теоријским поставкама: Џон Хачинсон, Магдалена Кох, Душан Иванић) упућује на посткласичну форму у опису Котора и которских сусрета.

Путопис Утисци с Пута по Нашој земљи представља драгоцено књижевно виђење градова и људи у Краљевини Југославији (1931), које је повезивао осећај заједништва, патриотизам и исти говор. Живописно су

\footnotetext{
Исто, 55.
}

10 Иcmo, 54. 
осликани карактери виђених жена из Кола српских сестара, као и њихова хуманитарна деловања, што је важно подсећање на значај овог удружења.

\section{Милунка Љ. Митић* \\ Вукова задужбина \\ Огранак у Нишу \\ Боривоја Гојковића 9 \\ 18000 Ниш} стара

Кључне речи: Јелена Димитријевић, Котор, сестре Кола српских сеMilunka Lj. Mitić

\section{KOTOR MEETINGS}

In the short travelogue Impressions from the Journey through Our Country, Jelena Dimitrijević takes quick notice of, for her significant, features of the cities of the Kingdom of Yugoslavia, through which she passed in the mission of the Circle of Serbian Sisters. And when it comes to encounters with people from those places, the writer, in the manner of segmental conversation, in hints, points to their characters.

However, the city of Kotor, together with the members of its Circle of Serbian Sisters Board, was plastically presented through miniature spiritual images of Kotor ladies. With a unique description of the evenings in the Bay of Kotor, this segment of the travelogue represents, above all, an apologetics of the meeting with the Kotor members of the Circle of Serbian Sisters.

\section{ЛИТЕРАТУРА}

Димитријевић 1931: Јелена Димитријевић, Са Конгреса, Београд: Мисао, јул-август, св. 252-256.

Димитријевић 1932: Јелена Димитријевић, Утисичи с Пута по Нашој Земљи, Београд: Вардар, стр. 51-58.

Ђурић 2018: Владимир Ђурић, Франиуска култура Јелене Димитријевић, „, Српска душа између Истока и Запада“. У: Зборник радова Читате ли Јелену Димитријевић?, уреднице: Биљана Дојчиновић и Јелена Милинковић, Београд: Филолошки факултет Универзитета у Београду.

* zlatana@ni.ac.rs 
Иванић 1996: Душан Иванић, Српски реализам, Нови Сад: Матица српска.

Кох 2004: Магдалена Кох, Епистоларна проза српских списатељииа прве половине 20. века. Жанровске особине, у: Прожимање жанрова y српској кьижевности, Научни састанак слависта у Вукове дане 2000, Београд: МСЦ.

Миленковић 2018: Јасмина Миленковић, Јелена Димитријевић и женска друштва. У: Зборник радова Читате ли Јелену Димитријевић?, уреднице: Биљана Дојчиновић и Јелена Милинковић, Београд: Филолошки факултет Универзитета у Београду.

Милосављевић 2005: Душан Милосављевић, Монографија КСС, Ниш: Просвета.

Митић 2015: Милунка Митић, Јелена Димитријевић - књижевни сведок свога времена (Из путописне прозе), Београд: Братство ХІХ, Друштво „Свети Сава“.

Секулић 1934: Исидора Секулић, Нови свет или у Америци годину дана. У: Книжевни преглед, Нова серија, XLIII, бр. 8, Београд: СКГ.

Hutchinson 1987: John Hutchinson, The Dynamics of Cultural Nationalism: The Gaelic Revival and the Creation of the Irish Nation State, London.

Шантић 1911: Алекса Шантић, Песме, Београд. 


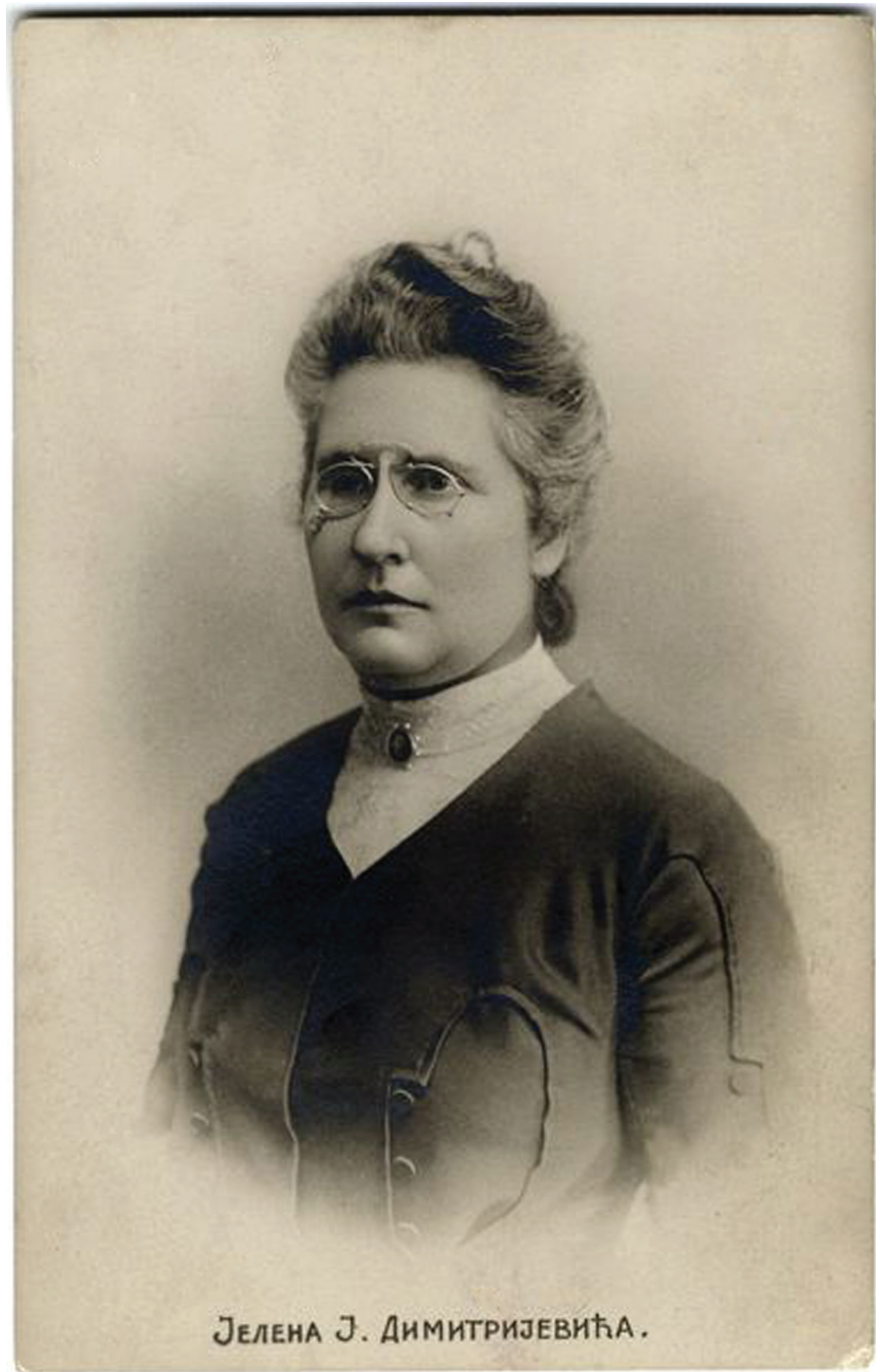

